\title{
Kompetensi Aparatur Desa, Komitmen Organisasi, Kejelasan Sasaran Anggaran dan Akuntabilitas Pengelolaan Dana Desa
}

\author{
Ni Made Suryani ${ }^{1}$ \\ Fakultas Ekonomi dan Bisnis \\ Universitas Udayana, Indonesia
}

\author{
Herkulanus Bambang Suprasto ${ }^{2}$ \\ Fakultas Ekonomi dan Bisnis \\ Universitas Udayana, Indonesia
}

\section{Surel : niimadesuryani@gmail.com \\ ABSTRAK}

Penelitian ini bertujuan untuk mengetahui pengaruh kompetensi aparatur desa, komitmen organisasi, kejelasan sasaran anggaran pada akuntabilitas pengelolaan dana desa. Sampel penelitian ini adalah 30 Desa di Kabupaten Buleleng dengan jumlah responden sebanyak 120 orang. Metode penentuan sampel menggunakan metode purposive sampling dan pengumpulan data menggunakan kuesioner. Teknik analisis data yang digunakan yaitu analisis regresi linear berganda. Hasil uji dari penelitian ini menunjukkan bahwa kompetensi aparatur desa, komitmen organisasi, dan kejelasan sasaran anggaran memiliki pengaruh positif terhadap akuntabilitas pengelolaan dana desa. Hasil penelitian ini membuktikan secara empiris bahwa teori stewardship dan teori kepatuhan berhasil terkonfirmasi dan mampu menjelaskan mengenai pengaruh kompetensi aparatur desa, komitmen organisasi, dan kejelasan sasaran anggaran terhadap akuntabilitas pengelolaan dana desa.

$\begin{array}{llccc}\text { Kata Kunci: } & \text { Kompetensi } & \text { Aparatur } & \text { Desa; } & \text { Komitmen } \\ & \text { Organisasi; } & \text { Kejelasan } & \text { Sasaran } & \text { Anggaran; } \\ & \text { Akuntabilitas. } & & & \end{array}$

\section{Village Apparatus Competence, Organizational Commitment, Clarity of Budget Targets and Accountability of Village Fund Management}

\begin{abstract}
This study aims to determine the effect of village apparatus competence, organizational commitment, clarity of budget targets on the accountability of village fund management. The sample of this research was 30 villages in Buleleng Regency with the number of respondents as many as 120 people. The method of determining the sample using purposive sampling method and data collection using a questionnaire. The data analysis technique used is multiple linear regression analysis. The test results of this study indicate that the competence of village officials, organizational commitment, and clarity of budget targets have a positive influence on the accountability of village fund management. The results of this study prove empirically that the stewardship theory and compliance theory have been confirmed and are able to explain the effect of village apparatus competence, organizational commitment, and clarity of budget targets on accountability of village fund management.
\end{abstract}

Keywords: Village Apparatus Competence; Organizational Commitment; Clarity of Budget Targets; Accountability.

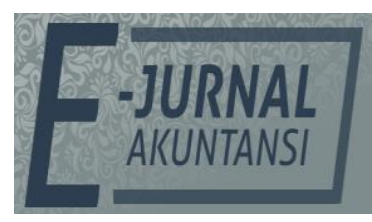

e-ISSN 2302-8556

Vol. 31 No. 8

Denpasar, Agustus 2021

Hal. 2011-2027

DOI:

10.24843/EJA.2021.v31.i08.p11

PENGUTIPAN:

Suryani, N.M., \& Suprasto, H.B. (2021). Kompetensi Aparatur Desa, Komitmen

Organisasi, Kejelasan

Sasaran Anggaran dan Akuntabilitas Pengelolaan

Dana Desa. E-Jurnal

Akuntansi, 30(8), 2011-2027

RIWAYAT ARTIKEL:

Artikel Masuk:

25 Maret 2021

Artikel Diterima:

15 Juni 2021

Artikel dapat diakses : https:/ / ojs.unud.ac.id/index.php/Akuntansi/index 


\section{PENDAHULUAN}

Undang-Undang No. 6 Tahun 2014 tentang desa menjadi fokus utama pemerintah Indonesia dalam meningkatkan pembangunan nasional. Desa memiliki wewenang dalam mengontrol pemerintah serta berbagai kepentingan masyarakat yang disesuaikan dengan potensi yang dimiliki desa, kondisi desa, dan aspirasi masyarakat demi mengutamakan pembangunan desa dan tercapainya kemandirian desa. Kewenangan yang diberikan kepada pemerintah desa dalam mengelola desa memberikan kemudahan kepada pemerintah pusat untuk menjalankan tugas dan tanggungjawabnya kepada seluruh masyarakat.

Hal ini dilakukan untuk menjawab persoalan adanya ketimpangan pembangunan di daerah pedesaan dengan perkotaan. Pembangunan yang dicanangkan pemerintah melalui desa direalisasikan dengan pemberian dana desa kepada seluruh desa di Indonesia. Semua proses pengelolaan dana desa harus didasari asas transparansi, akuntabel dan partisipatif. Dalam pengelolaan dana desa, dituntut adanya suatu aspek tata pemerintahan yang baik (good governance) dimana salah satu pilarnya adalah akuntabilitas.

Akuntabilitas merupakan kewajiban bagi setiap pemegang amanah untuk memberikan pertanggungjawaban, menyajikan, serta mengungkapkan setiap aktivitas yang dilakukan kepada pemberi amanah (principal) yang berhak dan memiliki kewajiban untuk mendapatkan pertanggungjawaban (Mardiasmo, 2009). Undang-Undang No. 6 Tahun 2014 menyatakan bahwa akuntabilitas merupakan asas yang digunakan dalam penyelenggaraan pemerintahan desa, artinya bahwa aparatur desa dalam mengelola keuangan desa haruslah mampu memberikan informasi terpercaya kepada masyarakat bahwa tata kelola keuangan desa ditujukan untuk meningkatkan kesejahteraan masyarakat. Masyarakat sebagai pihak yang memberi kepercayaan kepada pemerintah desa untuk mengelola keuangan desa berhak untuk mendapatkan informasi keuangan serta melakukan evaluasi terhadap pemerintah desa (Mardiasmo, 2009). Pemerintah desa dapat memanfaatkan anggaran yang telah disetujui dengan menetapkan beberapa kegiatan berdasarkan rencana yang telah ditetapkan (Windyastuti et al., 2019).

Dengan terwujudnya akuntabilitas pengelolaan dana desa diharapkan dapat mendukung otonomi desa agar pemerintahan desa dapat berjalan dengan baik. Akuntabilitas sangat penting dalam pengelolaan dana desa dikarenakan dapat memberikan gambaran dari sumber daya yang dikelola oleh pemerintah desa. Selain itu, terwujudnya akuntabilitas pengelolaan dana desa tidak lepas dari kompetensi yang dimiliki oleh aparatur desa. Hal ini menunjukkan bahwa semakin baik kompetensi yang dimiliki, maka pengelolaan dana desa akan dilakukan secara akuntabel. Selain itu, aparatur desa yang memiliki komitmen tinggi terhadap organisasinya (desa) akan menyusun kejelasan sasaran anggaran secara jelas sesuai dengan tujuan dari visi dan misi desa yang ingin dicapai dalam rencana kerja desa, sehingga berdampak pada peningkatan kinerja dalam organisasi (Widiyarta et al., 2017).

Berdasarkan data yang dihimpun dari situs resmi Direktorat Jenderal Perimbangan Keuangan Kementerian Keuangan, anggaran desa yang dicanangkan dalam APBN tahun anggaran 2019 mengalami peningkatan yaitu sebesar Rp70 triliun yang akan dialokasikan kepada kurang lebih sejumlah 
74,950 desa di Indonesia melalui perbaikan formulasi dengan memperhatikan aspek pemerataan dan keadilan. Pada tahun 2019, Provinsi Bali ikut mengalami peningkatan dana desa yang pada tahun sebelumnya Provinsi Bali mengalami penurunan penerimaan dana desa sekitar Rp531 miliar. Penurunan ini berimplikasi pada dana desa untuk masing-masing kabupaten/kota. Pada tahun 2019 provinsi Bali memperoleh dana sebesar Rp630,19 miliar (www.bali.antaranews.com). Optimalisasi pemanfaatan dana desa dilakukan untuk pemberdayaan masyarakat dan peningkatan perekonomian desa, penguatan kapasitas SDM dan tenaga pendamping desa, serta mengurangi tingkat kemiskinan dan menangani ketidakseimbangan dalam bidang pembangunan antar desa di seluruh Indonesia.

Apabila ditinjau dari luas dan jumlah desanya, Kabupaten Buleleng mempunyai 129 desa sekaligus kabupaten terluas di Provinsi Bali. Sumbersumber pendapatan desa yang dikirimkan dari pemerintah pusat seperti dana desa yang diambil dari Anggaran Pendapatan dan Belanja Negara (APBN) dan memang sudah dialokasikan untuk desa minimal 10 persen dari APBN dan nantinya akan dicairkan ke desa melalui tiga tahap yaitu tahap I disalurkan sebesar 20 persen, tahap II dan Tahap III disalurkan sebesar 40 persen (Permenkeu No. 193 Tahun 2018). Dana yang telah diberikan harus digunakan dan dikelola secara tepat serta terkontrol (Wibowo, 2019).

Adanya perbedaan alokasi dana yang diterima oleh masing-masing desa disebabkan oleh beberapa faktor, yaitu jumlah penduduk, angka kemiskinan, luas wilayah dan tingkat kesulitan geografis. Dana desa dilaksanakan secara swakelola yang diutamakan dengan menggunakan sumber daya dan bahan lokal, untuk menghasilkan tenaga yang tersedia di desa tersebut (Fatmawati et al., 2018). Pada kenyataannya di lapangan terdapat banyak desa yang kurang optimal dalam mengelola dana desanya, sehingga akuntabilitas pengelolaan dana desa di Kabupaten Buleleng ini masih belum tercapai. Hal ini dibuktikan karena adanya reaksi atas laporan-laporan bermunculan yang menganggap bahwa pengelolaan dana desa tidak dilakukan dengan transparan dan akuntabel di Kabupaten Buleleng.

Berdasarkan data yang disampaikan oleh Dinas Pemberdayaan Masyarakat Desa (PMD) dalam berita yang dirilis oleh Balipuspanews pada tanggal 12 September 2019, terdapat 29 desa di Kabupaten Buleleng yang terancam tidak dapat mencairkan dana desa tahap III karena tidak mematuhi aturan yang berlaku yaitu belum menyelesaikan Laporan Realisasi Anggaran (LRA) dan Laporan Pertanggungjawaban (LPJ) tahap I dan tahap II (Ardi, 2019). Faktor pertama yang mungkin dapat mempengaruhi terlambatnya penyelesaian Laporan Realisasi Anggaran (LRA) dan Laporan Pertanggungjawaban (LPJ) adalah kompetensi aparatur desa yang masih kurang paham dalam menyusun anggaran desa sesuai persyaratannya (Aryani et al., 2020). Permendagri No. 20 Tahun 2018 menjelaskan bahwa laporan yang disampaikan oleh Kepala Desa merupakan bentuk pertanggungjawaban atas dana yang diperoleh dan juga sebagai syarat pencairan dana desa. Maka dari itu, pelaporan LRA dan LPJ yang tepat waktu merupakan bentuk terwujudnya suatu akuntabilitas.

Besarnya jumlah dana desa yang disalurkan pemerintah guna untuk peningkatan kesejahteraan masyarakat. Hal ini juga berakibat pada 
kekhawatiran masyarakat akan terjadinya penyalahgunaan dana desa yang jumlahnya relatif sangat besar. Ada empat faktor yang menyebabkan terjadinya korupsi dana desa menurut Indonesia Corruption Watch (ICW), yaitu; kurang dilibatkannya masyarakat dalam proses perencanaan dan pengawasan dana desa, terbatasnya kompetensi kepala desa dan perangkat desa, tidak optimalnya lembaga desa, dan cost politik yang tinggi akibat kompetitifnya arena pemilihan kepala desa (Sjafrina et al., 2017).

Buruknya kinerja akuntabilitas bisa dilihat dari banyaknya aparatur yang menyimpan dana desa untuk kepentingan pribadi dari pada untuk merealisasikannya bagi masyarakat. Berdasarkan data yang disampaikan dalam berita yang dirilis oleh Baliexpress pada 14 Juli 2020, Aparatur Desa TG Kecamatan Banjar, Kabupaten Buleleng terjerat kasus dugaan dalam penyalahgunaan dana desa yang sudah dilaporkan pada tahun 2019. Dana APBDesa yang diperoleh sekitar Rp1.000.000.000 dan dana tersebut akan dialokasikan untuk pelaksanaan proyek pembangunan bak penampungan air minum di tiga titik, serta untuk proyek penyenderan jalan. Proyek tersebut seharusnya tuntas dikerjakan hingga akhir 2019. Pada bulan Juni 2020, pihak apparat desa baru mengerjakan proyek tersebut. Seorang perwakilan warga Desa TG, menemukan bukti adanya pelaporan keuangan fiktif yang dibuat oleh pelaksana kegiatan anggaran (PKA) agar seolah-olah laporan ke DPMD Buleleng, proyek tersebut sudah tuntas dikerjakan (Suarna, 2020)

Besarnya dana desa yang diperoleh Kabupaten Buleleng ditambah dengan adanya kasus sejumlah desa yang ada Kabupaten Buleleng mengalami keterlambatan dalam melaporkan pertanggungjawabannya serta penyalahgunaan dana desa pada tahun 2019 yang menggambarkan rendahnya akuntabilitas dari aparatur desa di Kabupaten Buleleng. Dapat disimpulkan terjadinya fenomena di atas dikarenakan aparatur desa tidak memenuhi kepatuhan pada aturan lingkungan organisasi, masyarakat, dan pemerintah dalam pertanggungjawaban keuangan secara formal (Mahayani, 2017).

Dalam mengelola dana desa yang besar diperlukan aparatur yang memiliki kompetensi yang tinggi seperti pengetahuan, keterampilan, kemampuan, dan sikap yang sesuai dengan jabatan yang diembannya akan selalu terdorong untuk bekerja secara efektif, efisien, dan produktif (Ladapase, 2019). Penelitian sebelumnya yang dilakukan oleh Atmadja \& Saputra (2018), Dewi \& Gayatri (2019), dan Medianti (2018) menyimpulkan bahwa kompetensi aparatur berpengaruh signifikan terhadap akuntabilitas pengelolaan dana desa. Penelitian tersebut sejalan dengan penelitian yang dilakukan oleh Aulia (2018), menyimpulkan bahwa hasil penelitian menyatakan bahwa kompetensi sumber daya manusia merupakan salah satu faktor yang mempengaruhi akuntabilitas pengelolaan dana desa. Hasil berbeda diperoleh dalam penelitian yang dilakukan oleh Widyatama et al. (2017) menyimpulkan bahwa kompetensi secara signifikan berpengaruh negatif terhadap akuntabilitas pemerintah desa dalam mengelola alokasi dana desa.

Aparatur organisasi pemerintah desa harus memiliki komitmen organisasi sebagai pertanggungjawaban kepada masyarakat desa demi menciptakan akuntabilitas ke arah yang lebih baik (Indrayani et al., 2017). Hasil penelitian sebelumnya yang dilakukan oleh Nurdin \& Wijaya (2019), menyatakan bahwa 
komitmen organisasi pemerintah desa berpengaruh positif terhadap akuntabilitas pengelolaan dana desa karena semakin tingginya tingkat kesadaran kita atau tingkat komitmen kita terhadap organisasi atau instansi dalam hal komitmen organisasi pemerintah desa, maka akan semakin baik akuntabilitas pengelolaan dana desa. Penelitian ini sejalan dengan penelitian sebelumnya yang dilakukan oleh Mada et al. (2017), Nurdin \& Wijaya (2019), Rulyanti et al. (2018), dan Utari \& Sujana (2019) menyimpulkan bahwa bahwa komitmen OPD memiliki pengaruh positif pada akuntabilitas pengelolaan dana desa. Berbeda dengan hasil penelitian yang dilakukan oleh Alminanda \& Marfuah (2018) menunjukkan bahwa komitmen organisasi pemerintah desa berpengaruh negatif terhadap akuntabilitas pengelolaan dana desa.

Adanya kejelasan sasaran anggaran, maka target-target sasaran yang ingin dicapai organisasi dapat disusun dengan baik, sehingga dapat mendorong terciptanya akuntabilitas dalam pengelolaan dana desa. Penelitian sebelumnya yang dilakukan oleh Arta \& Rasmini (2019), Judarmita \& Supadmi (2017), Wijaya \& Suardana (2020), dan Yoga \& Wirawati (2020) menyimpulkan bahwa kejelasan sasaran anggaran berpengaruh signifikan terhadap akuntabilitas pengelolaan dana desa. Berbeda dengan hasil penelitian yang dilakukan oleh Afrida (2017) menunjukkan hasil yang berbeda bahwa kejelasan sasaran anggaran berpengaruh negatif terhadap akuntabilitas kinerja pemerintah daerah.

Hasil-hasil penelitian tersebut menunjukkan masih adanya ketidak konsistenan mengenai pengaruh kompetensi apartur desa, komitmen organisasi, dan kejelasan sasarn anggaran terhadap akuntabilitas pengelolaan dana desa yang mendorong peneliti untuk melakukan replikasi riset terdahulu. Salah satu faktor penyebab ketidak konsistenan tersebut adalah belum optimalnya para aparatur desa dalam mengelola anggaran dana desa untuk meningkatkan akuntabilitas.

Alasan peneliti menggunakan desa yang berada di wilayah Kabupaten Buleleng sebagai lokasi penelitian karena Kabupaten Buleleng merupakan kabupaten yang mendapatkan dana desa terbesar di Provinsi Bali yaitu sebesar Rp124.026.738.000 guna meningkatkan kesejahteraan masyarakat melalui akuntabilitas pengelolaan dana desa, namun fakta di lapangan menyatakan bahwa desa yang berada Kabupaten Buleleng tersebut terlibat kasus yang menunjukkan bahwa akuntabilitas di Kabupaten Buleleng masih rendah. Berbeda dengan penelitian sebelumnya, yang telah dilakukan oleh beberapa peneliti mengenai akuntabilitas pengelolaan dana desa, dalam penelitian ini dipilih beberapa desa di Kabupaten Buleleng sebagai lokasi penelitian.

Teori stewardship menjelaskan kompetensi aparatur desa dilihat dari bagaimana aparatur desa (steward) dapat menciptakan keputusan serta menentukan tindakan yang paling tepat untuk tujuan optimalisasi kinerja perusahaan yang dipimpinnya (Rahayu \& Gudono, 2016). Terkait dengan teori stewardship kesuksesan pemerintah desa (steward) yang dinilai oleh prinsipal menunjukan bahwa pemerintah desa bekerja dengan mendahulukan kepentingan organisasi/ lembaga (Asmawati \& Basuki, 2019). Dengan demikian teori stewardship adalah teori yang sesuai dalam penelitian ini dimana setiap aparatur desa memiliki tujuan yang sama untuk memperbaiki desa guna mensejahterakan masyarakat dengan cara memberikan pelayanan yang baik, 
sehingga dapat tercapai akuntabilitas dana desa dengan terpenuhinya laporan pertanggungjawaban yang baik sesuai dengan hukum dan ketentuan yang berlaku.

Berdasarkan teori kepatuhan, aparatur desa dalam mengelola dana desa harus penuh kepatuhan pada berbagai peraturan dan ketentuan yang berlaku, sehingga pemanfaatan dalam mengelola dana desa sesuai dengan yang diamanatkan dalam Undang-Undang (Dewi \& Gayatri, 2019). Kompetensi aparatur desa merupakan kemampuan yang dimiliki oleh aparatur desa dalam melakukan suatu kegiatan atau pekerjaan dan masing-masing individu memiliki kemampuan yang berbeda-beda dilihat dari berbagai aspek dapat berupa pengetahuan, kemampuan (skill) baik softskill maupun hardskill, dan sikap atau perilaku yang dimiliki individu (Edison et al., 2016).

Penelitian tentang kompetensi aparatur desa yang dilakukan oleh Atmadja \& Saputra (2018), Dewi \& Gayatri (2019), Hardiningsih et al. (2020) dan Medianti (2018) memberikan kesimpulan yang sama yaitu kompetensi aparatur desa berpengaruh positif terhadap akuntabilitas pengelolaan dana desa. Penelitian ini sejalan juga yang diperoleh Aulia (2018) menyimpulkan bahwa kompetensi sumber daya manusia merupakan salah satu faktor yang mempengaruhi akuntabilitas pengelolaan dana desa.

Dapat disimpulkan apabila semakin tinggi kompetensi aparatur desa dalam mewujudkan akuntabilitas, maka aparatur desa dipercaya dapat mempertanggungjawaban kinerja dalam mengelola keuangan desa sesuai dengan amanah dan kepercayaan yang diberikan kepadanya, sehingga pada saat pengambilan keputusan dalam penggunaan dana desa akan menghasilkan keputusan yang terbaik guna memberikan pelayanan yang terbaik sesuai dengan tugas yang seharusnya seorang aparatur desa (Mada et al., 2017).

$\mathrm{H}_{1}$ : Kompetensi apartur desa yang semakin baik akan meningkatkan akuntabilitas pengelolaan dana desa

Implikasi dari teori stewardship yaitu pihak yang dipercaya dalam akuntabilitas pengelolaan dana desa adalah aparatur desa. Aparatur desa yang memilki komitmen organisasi yang tinggi akan mempertanggungjawabkan segala kegiatan yang dilakukannya dalam organisasi untuk mewujudkan pelayanan yang baik kepada public dan dapat mencapai pengelolaan anggaran yang efektif, sehingga dengan tingginya komitmen organisasi, aparatur desa dapat selalu bertindak hati-hati dan memberikan dampak positif bagi desa. Komitmen organisasi merupakan suatu sikap ataupun kesiapan setiap individu yang berada di dalam sebuah organisasi/instansi pemerintahan dan tertarik dengan budaya, tujuan, dan sasaran organisasi sesuai visi dan misi, dimana individu tersebut tetap ingin berada dalam suatu organisasi tersebut (Rulyanti et al., 2018).

Penelitian komitmen organisasi yang dilakukan oleh Handayani. \& Setiawan (2019), Nurdin \& Wijaya (2019), Rulyanti et al. (2018), dan Utari \& Sujana (2019) memberikan hasil penelitian yaitu komitmen organisasi berpengaruh positif terhadap akuntabilitas pengelolaan dana desa. Selain itu penelitian dari Mariska et al. (2018) menunjukkan bahwa komitmen berpengaruh terhadap akuntabilitas pengelolaan keuangan desa karena aparatur desa yang memiliki komitmen terhadap organisasi akan mengupayakan kemampuannya 
untuk mewujudkan pencapaian dari tujuan organisasi dimana akuntabilitas termasuk di dalamnya. Hal ini didukung oleh Mada et al. (2017) menyimpulkan bahwa komitmen organisasi berpengaruh positif terhadap akuntabilitas dana desa karena dengan komitmen yang tinggi suatu desa dapat mencapai akuntabilitas. Aparat desa yang merasa target anggaran sudah jelas akan lebih bertanggung jawab jika didukung dengan komitmen aparatur yang tinggi kepada organisasi (instansi).

$\mathrm{H}_{2}$ : Komitmen organisasi yang semakin baik meningkatkan akuntabilitas pengelolaan dana desa.

Implikasi teori stewardship terhadap penelitian ini, dapat menjelaskan eksistensi aparatur desa (steward) memiliki kewajiban untuk memberikan pertanggungjawaban, menyajikan, melaporkan, dan mengungkapkan segala aktivitas dan kegiatan yang menjadi tanggung jawabnya melalui kejelasan sasaran anggaran (Lewier \& Kurniawan, 2016). Tercapainya akuntabilitas dana desa didukung dengan penggunaan keuangan desa yang memadai dan dikelola dengan baik oleh aparatur desa sesuai dengan tujuan sasaran anggaran dana desa yang telah ditetapkan. Selain itu, kejelasan sasaran anggaran berkaitan dengan konsep dari teori kepatuhan karena mampu mencegah terjadinya tindak kecurangan atau ketidakpatuhan oleh perangkat desa dalam menjalankan tugasnya. Proses penyusunan anggaran juga harus memerhatikan aturan-aturan yang berlaku, sehingga dapat mewujudkan akuntabilitas. Kejelasan sasaran anggaran adalah sejauh mana tujuan anggaran ditetapkan secara jelas dan spesifik dengan tujuan anggaran dapat dimengerti oleh orang yang bertanggungjawab atas pencapaian sasaran anggaran tersebut (Kenis, 1979). Kejelasan sasaran anggaran yang spesifik artinya target anggaran yang ingin dicapai harus ditentukan dan dirinci agar tidak menimbulkan interpretasi yang beragam (Pebrianti \& Aziza, 2019).

Penelitian tentang kejelasan sasaran anggaran yang dilakukan oleh Arta \& Rasmini (2019), Judarmita \& Supadmi (2017), Supadmi \& Suputra (2018), dan Yoga \& Wirawati (2020) memberikan kesimpulan yang sama yaitu kejelasan sasaran anggaran berpengaruh positif terhadap akuntabilitas pengelolaan dana desa. Hal ini sejalan dengan penelitian yang dilakukan oleh Wijaya \& Suardana (2020) yang membuktikan bahwa kejelasan sasaran anggaran berpengaruh positif pada akuntabilitas dana desa karena kejelasan sasaran yang hendak dituju akan mempermudah pengelola guna melaksanakan anggaran dan juga mempertanggungjawabkannya. Kejelasan sasaran anggaran akan memudahkan aparatur desa untuk menyusun rencana kegiatan dengan tujuan yang ingin dicapai.

$\mathrm{H}_{3}$ : Kejelasan sasaran anggaran yang semakin baik meningkatkan akuntabilitas pengelolaan dana desa.

\section{METODE PENELITIAN}

Penelitian ini dilakukan dengan menggunakan pendekatan kuantitatif yang berbentuk penelitian asosiatif. Metode pengumpulan data yang digunakan dalam penelitian ini adalah metode kuesioner. Kuesioner dalam penelitian ini disusun menggunakan skala likert 1 sampai 5 . Populasi dalam penelitian ini adalah aparatur desa yang berada di seluruh desa se-Kabupaten Buleleng 
sebanyak 129 desa. Metode penentuan sampel yang akan digunakan pada penelitian ini adalah metode non-probability sampling yaitu teknik purposive sampling. Sampel pada penelitian ini terdapat 30 desa berdasarkan kriteria, dengan masing-masing 4 aparatur desa yang terlibat langsung dalam pengelolaan keuangan desa yaitu Kepala Desa (Perbekel), Sekretaris Desa, Kepala Urusan Keuangan Desa (Bendahara Desa), dan Kaur Perencanaan dengan jumlah responden sebanyak 120 orang.

Variabel kompetensi aparatur desa $\left(\mathrm{X}_{1}\right)$ dapat diukur dengan indikator pengetahuan (knowledge), perilaku (attitude), keahlian (skill). Variabel komitmen organisasi $\left(\mathrm{X}_{2}\right)$ dapat diukur dengan indikator komitmen afektif, komitmen berkelanjutan, komitmen normative. Variabel kejelasan sasaran anggaran $\left(X_{3}\right)$ dapat diukur dengan indikator jelas, skala prioritas, dan spesifik. Variabel akuntabilitas $(\mathrm{Y})$ dapat diukur dengan indikator perencanaan, pelaksanaan, penatausahaan, pelaporan, dan pertanggungjawaban. Adapun teknik analisis data yang digunakan adalah analisis statistic deskriptif, uji asumsi klasik, analisis regresi linear berganda, uji koefisien determinasi $\left(R^{2}\right)$, uji kelayakan model (uji F), uji hipotesis (uji t). Model regresi berganda dirumuskan dalam bentuk persamaan sebagai berikut.

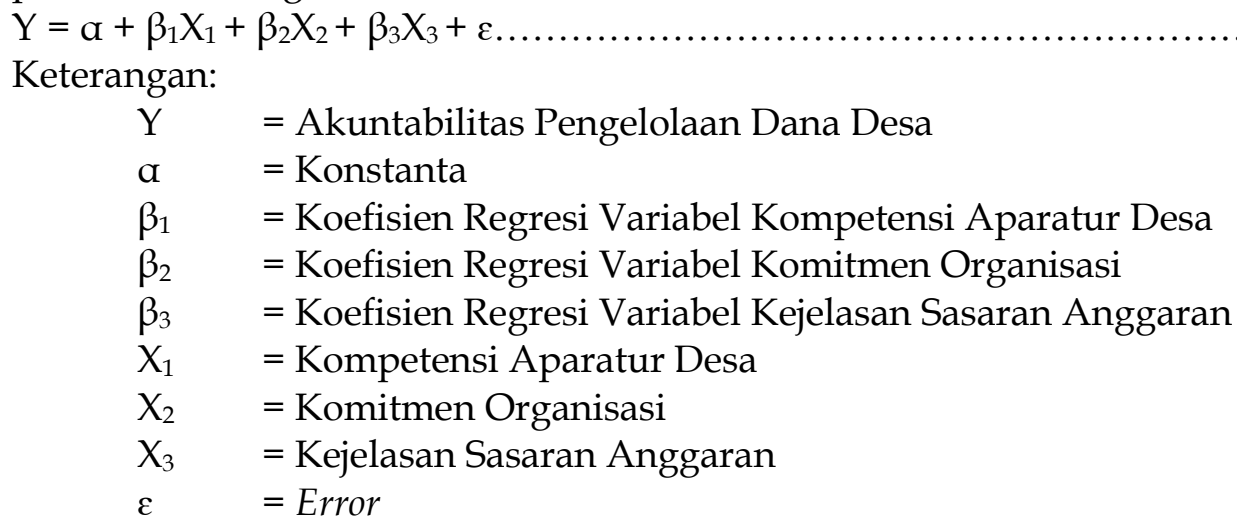

\section{HASIL DAN PEMBAHASAN}

Tingkat pengembalian kuesioner adalah sebesar 100 persen. Berdasarkan kuesioner yang terkumpul, semua kuesioner diisi dengan baik oleh responden, sehingga semua kuesioner dapat digunakan. Berdasarkan 120 kuesioner yang digunakan dalam penelitian ini, maka dapat digambarkan karakteristik responden berdasarkan demografi yang digambarkan melalui variabel usia, pendidikan terakhir, dan lama bekerja. Data mengenai variabel demografi disajikan dalam Tabel 1.

Responden dalam penelitian ini sebagian besar berusia antara 36-50 tahun. Aparatur desa dengan usia tersebut termasuk usia yang tergolong memiliki kematangan dalam karir dan berfikir, sehingga aparatur desa dianggap mampu untuk menyelesaikan permasalahan yang dihadapi dalam proses pelaksanaan anggaran dan mewujudkan akuntabilitas pengelolaan dana desa.

Berdasarkan Tabel 1, dapat diketahui responden dengan pendidikan terakhir SMA berjumlah 72 orang (60,0 persen), pendidikan terakhir D1 berjumlah 6 orang (5,0 persen), pendidikan terakhir D2 berjumlah 4 orang (3,3 
persen), pendidikan terakhir D3 berjumlah 11 orang (9,2 persen), dan responden dengan pendidikan terakhir S1 berjumlah 27 responden atau (22,5 persen).

Aparatur desa sebagian besar berlatar belakang pendidikan SMA. Dengan latar belakang pendidikan yang dimiliki serta adanya kemauan dari aparatur desa untuk mengikuti pelatihan mengenai pengelolaan dana desa, maka dalam melaksanakan tugasnya aparatur desa mampu mengelola dana desa dengan baik, sehingga dapat mewujudkan akuntabilitas pengelolaan dana desa (Wijaya \& Suardana, 2020).

Berdasarkan Tabel 1, dapat diketahui responden dengan lama bekerja $<1$ tahun berjumlah 8 orang (6,7 persen), responden dengan lama bekerja $1-5$ tahun berjumlah 73 orang (60,8 persen), dan responden dengan lama bekerja $>5$ tahun sebanyak 39 orang (32,5 persen). Hal ini dapat disimpulkan bahwa responden dalam penelitian ini sebagian besar memiliki pengalaman bekerja cukup lama yaitu antara 1-5 tahun.

Lama bekerja menunjukkan seberapa mampu aparatur desa dalam menyelesaikan tugasnya. Semakin lama aparatur desa bekerja dalam suatu organisasi desa, maka aparatur desa tersebut akan memiliki pengalaman dalam menciptakan kemampuan atas kinerjanya untuk melaksanakan tugas-tugas yang dimiliki. Dengan demikian perpaduan antara pengalaman dan adanya kemauan untuk belajar akan lebih meningkatkan pengetahuan teknis maupun keterampilan kerja, sehingga aparatur desa akan lebih mahir dalam mengelola dana desa dengan baik dan mampu mencapai tujuan yang diharapkan yaitu terwujudnya akuntabilitas pengelolaan dana desa.

Tabel 1. Data Karakteristik Responden

\begin{tabular}{|c|c|c|c|c|}
\hline No & Variabel & Klasifikasi & Jumlah & $\begin{array}{l}\text { Presentase } \\
\text { persen) }\end{array}$ \\
\hline & Usia & 20 - 35 Tahun & 21 & 17,5 \\
\hline \multirow[t]{2}{*}{1} & & 36 - 50 Tahun & 62 & 51,7 \\
\hline & & > 50 Tahun & 37 & 30,8 \\
\hline \multicolumn{2}{|c|}{ Jumlah } & & 120 & 100 \\
\hline & Pendidikan & SMA & 72 & 60,0 \\
\hline & Terakhir & D1 & 6 & 5,0 \\
\hline \multirow[t]{3}{*}{2} & & D3 & 11 & 9,2 \\
\hline & & S1 & 27 & 22,5 \\
\hline & & D2 & 4 & 3,3 \\
\hline \multicolumn{2}{|c|}{ Jumlah } & & 120 & 100 \\
\hline & Lama Bekerja & $<1$ Tahun & 8 & 6,7 \\
\hline \multirow[t]{2}{*}{3} & & 1 - 5 Tahun & 73 & 60,8 \\
\hline & & > 5 Tahun & 39 & 32,5 \\
\hline \multicolumn{2}{|c|}{ Jumlah } & & 120 & 100 \\
\hline
\end{tabular}

Sumber: Data Penelitian, 2020

Menurut Sugiyono (2017) uji validitas digunakan untuk mengukur sah atau tidaknya suatu kuesioner. Instrument pengumpulan data yang digunakan pada penelitian ini berupa kuesioner, setiap instrumen dapat dikatakan valid apabila memiliki nilai koefisien korelasi $\geq 0,30$. Hasil uji validitas pada lampiran 3 menunjukkan bahwa seluruh instrumen penelitian yang digunakan untuk mengukur variabel kompetensi aparatur desa, komitmen organisasi, kejelasan sasasaran anggaran, dan akuntabilitas pengelolaan dana desa memiliki nilai 
koefisien korelasi dengan skor total seluruh item pernyataan lebih besar dari 0,30 . Hal ini menunjukkan bahwa butir-butir pernyataan dalam instrumen penelitian tersebut valid dan layak digunakan sebagai instrument penelitian.

Uji realiabilitas ini bertujuan untuk mengetahui apakah kuesioner yang digunakan dalam penelitian ini menunjukan tingkat ketepatan, keakuratan, dan konsistensi meskipun kuesioner ini digunakan dua kali atau lebih pada lain waktu. Suatu instrumen dikatakan reliabel apabila nilai cronbach's alpha lebih dari 0,60 (Ghozali, 2018). Rekapitulasi hasil uji reliabilitas instrumen penelitian dapat dilihat pada Tabel 2.

Tabel 2. Rekapitulasi Hasil Uji Reliabilitas Instrumen Penelitian

\begin{tabular}{llll}
\hline \multirow{2}{*}{ No. } & \multirow{2}{*}{ Variabel } & $\begin{array}{l}\text { Cronbach's } \\
\text { Alpha }\end{array}$ & Keterangan \\
\hline 1 & Kompetensi Aparatur Desa $\left(\mathrm{X}_{1}\right)$ & 0,961 & Reliabel \\
2 & Komitmen Organisasi $\left(\mathrm{X}_{2}\right)$ & 0,974 & Reliabel \\
3 & Kejelasan Sasaran Anggaran $\left(\mathrm{X}_{3}\right)$ & 0,899 & Reliabel \\
4 & Akuntabilitas Pengelolaan Dana Desa $(\mathrm{Y})$ & 0,957 & Reliabel \\
\hline
\end{tabular}

Sumber: Data penelitian, 2021

Hasil uji reliabilitas yang disajikan dalam Tabel 2, menunjukkan bahwa seluruh instrumen penelitian memiliki koefisien Cronbach's Alpha lebih dari 0,60. Jadi dapat dinyatakan bahwa seluruh variabel telah memenuhi syarat reliabilitas atau kehandalan sehingga data penelitian ini dapat dipercaya.

Uji normalitas bertujuan untuk mengetahui apakah residual dari model regresi yang dibuat berdistribusi normal atau tidak. Jika probabilitas signifikansi nilai residual lebih besar dari 0,05 maka data tersebut dikatakan berdistribusi normal. Demikian pula sebaliknya, jika probabilitas signifikansi residual lebih rendah dari 0,05 maka data tersebut dikatakan tidak berdistribusi normal. Setelah melakukan pengujian, nilai signifikansi dengan menggunakan uji Asymp. Sig. (2-tailed) sebesar 0,845 > 0,05 maka dapat disimpulkan bahwa data dalam model regresi yang digunakan dalam penelitian ini terdistribusi secara normal.

Uji multikolonieritas bertujuan untuk menguji apakah model regresi ditemukan adanya korelasi antara variabel bebas. Uji multikolinearitas dilakukan dengan melihat nilai tolerance dan variance inflation factor (VIF). Jika nilai tolerance lebih besar dari 0,1 dan VIF kurang dari 10, maka data terbebas dari kasus multikolinearitas.

Tabel 3. Hasil Uji Multikolinieritas

\begin{tabular}{llcc} 
& & \multicolumn{2}{c}{ Collinearity Statistics } \\
\cline { 2 - 3 } Model & Kompetensi Aparatur Desa & 0,441 & VIF \\
\hline \multirow{2}{*}{1} & Komitmen Organisasi & 0,498 & 2,270 \\
\cline { 2 - 3 } & Kejelasan Sasaran Anggaran & 0,629 & 2,009 \\
\multicolumn{2}{c}{ a. Dependent Variable: Akuntabilitas Pengelolaan Dana Desa } & 1,589
\end{tabular}

Sumber: Data Penelitian, 2021

Berdasarkan hasil uji pada Tabel 3, dapat diketahui bahwa nilai tolerance untuk variabel kompetensi aparatur desa sebesar 0,441 $(0,441>0,1)$ dengan nilai VIF sebesar 2,270 $(2,270<10)$, nilai tolerance untuk variabel komitmen organisasi sebesar 0,498 $(0,498>0,1)$ dengan nilai VIF sebesar 2,009 $(2,009<10)$, dan nilai tolerance untuk variabel kejelasan sasaran anggaran sebesar 0,629 $(0,629>0,1)$ 
dengan nilai VIF sebesar $1,589(1,589<10)$. Semua variabel pada model regresi berganda tersebut memiliki nilai tolerance lebih besar dari 0,1 dan nilai VIF lebih kecil dari 10 maka dapat disimpulkan bahwa model regresi yang digunakan bebas multikolinieritas.

Uji heteroskedastisitas ini bertujuan untuk mengetahui apakah dalam model regresi terjadi ketidaksamaan varians dari residual satu pengamatan ke pengamatan lain yang dilakukan dengan uji Glejser. Jika variabel bebas yang diteliti tidak mempunyai pengaruh signifikan atau nilai signifikansinya lebih dari 0,05 terhadap nilai absolute residual, berarti model regresi tidak mengandung gejala heteroskedastisitas. Setelah dilakukan pengujian, didapatkan nilai signifikan untuk variabel kompetensi aparatur desa sebesar 0,604 $(0,604>0,05)$, nilai signifikan untuk variabel komitmen organisasi sebesar 0,179 $(0,179>0,05)$, dan nilai signifikan untuk variabel kejelasan sasaran anggaran sebesar 0,354 $(0,354>0,05)$. Semua variabel bebas memiliki nilai signifikansi lebih besar dari 0,05, maka tidak terjadi heteroskedastisitas pada model regresi.

Tabel 4. Hasil Uji Hipotesis (Uji t)

\begin{tabular}{|c|c|c|c|c|c|}
\hline \multirow[b]{2}{*}{ Model } & \multicolumn{2}{|c|}{$\begin{array}{c}\text { Unstandardized } \\
\text { Coefficients }\end{array}$} & \multirow{2}{*}{$\begin{array}{c}\text { Standardized } \\
\text { Coefficients } \\
\text { Beta }\end{array}$} & \multirow[b]{2}{*}{ Sig. } & \multirow{2}{*}{$\begin{array}{l}\text { Hasil Uji } \\
\text { Hipotesis }\end{array}$} \\
\hline & B & Std. Error & & & \\
\hline \multirow{4}{*}{$\begin{array}{ll} & (\text { Constant }) \\
& \text { Kompetensi Aparatur } \\
1 & \text { Desa } \\
\text { Komitmen Organisasi } \\
\text { Kejelasan Sasaran } \\
\text { Anggaran }\end{array}$} & 14,619 & 3,612 & & 0,000 & $\mathrm{H}_{1}$ diterima \\
\hline & 0,216 & 0,089 & 0,197 & 0,017 & $\mathrm{H}_{2}$ diterima \\
\hline & 0,572 & 0,078 & 0,565 & 0,000 & $\mathrm{H}_{3}$ diterima \\
\hline & 0,356 & 0,162 & 0,151 & 0,029 & $\mathrm{H}_{4}$ diterima \\
\hline
\end{tabular}

a. Dependent Variable: Akuntabilitas Pengelolaan Dana Desa

Sumber: Data Penelitian, 2021

Hasil pengujian hipotesis mengenai pengaruh kompetensi aparatur desa terhadap akuntabilitas pengelolaan dana desa diperoleh nilai signifikansi sebesar 0,017 lebih kecil dari $a=0,05$ yang mengindikasikan bahwa hipotesis pertama diterima. Hasil ini menunjukkan bahwa kompetensi aparatur desa berpengaruh positif terhadap akuntabilitas pengelolaan dana desa. Hasil deskripsi jawaban responden menunjukkan kompetensi aparatur desa secara keseluruhan baik, hal ini dapat dilihat dari keseluruhan rata-rata nilai kompetensi aparatur desa yaitu 4,18. Nilai rata-rata tertinggi pada pernyataan "Saya sebagai aparatur desa mampu berkomunikasi dan memberi informasi pelayanan dengan baik" dengan nilai rata-rata 4,31. Hal ini menunjukkan bahwa aparatur desa sudah menjalankan tugas-tugasnya dengan baik, sehingga informasi mengenai desa dapat diterima oleh masyarakat dan instansi lainnya.

Teori stewardship menjelaskan bahwa kompetensi aparatur desa dilihat dari bagaimana aparatur desa (steward) dapat menciptakan keputusan serta menentukan tindakan yang paling tepat untuk tujuan optimalisasi kinerja perusahaan yang dipimpinnya (Rahayu \& Gudono, 2016), sehingga pada saat pengambilan keputusan dalam penggunaan dana desa akan menghasilkan keputusan yang terbaik guna memberikan pelayanan sesuai dengan tugas yang seharusnya seorang aparatur desa. Dengan demikian teori stewardship adalah teori yang sesuai dalam penelitian ini dimana setiap aparatur desa memiliki tujuan yang sama yaitu lebih menjunjung tujuan perusahaan dibandingkan 
dengan tujuan perorangan, sehingga dapat tercapai akuntabilitas pengelolaan dana desa. Berdasarkan teori kepatuhan, aparatur desa dalam mengelola dana desa harus penuh kepatuhan pada berbagai peraturan dan ketentuan yang berlaku serta keterbukaan informasi kepada masyarakat, sehingga pemanfaatan dalam mengelola dana desa sesuai dengan yang diamanatkan dalam UndangUndang (Dewi \& Gayatri, 2019).

Kompetensi aparatur desa merupakan kemampuan yang dimiliki oleh aparatur desa dalam melakukan suatu kegiatan atau pekerjaan dan masingmasing individu memiliki kemampuan yang berbeda-beda dilihat dari berbagai aspek dapat berupa pengetahuan, kemampuan (skill) baik softskill maupun hardskill, dan sikap atau perilaku yang dimiliki individu (Edison et al., 2016). Tingginya kompetensi yang dimiliki oleh aparatur desa akan mendukung keberhasilan mewujudkan akuntabilitas pengelolaan dana desa.

Hasil penelitian ini sejalan dengan penelitian yang dilakukan oleh Atmadja \& Saputra (2018), Dewi \& Gayatri (2019), Hardiningsih et al. (2020), dan Medianti (2018) memberikan kesimpulan yang sama yaitu kompetensi aparatur desa berpengaruh positif terhadap akuntabilitas pengelolaan dana desa. Penelitian ini sejalan juga yang diperoleh Aulia (2018) menyimpulkan bahwa kompetensi sumber daya manusia merupakan salah satu faktor yang mempengaruhi akuntabilitas pengelolaan dana desa.

Hasil pengujian hipotesis mengenai pengaruh komitmen organisasi terhadap akuntabilitas pengelolaan dana desa diperoleh nilai signifikansi sebesar 0,000 lebih kecil dari $a=0,05$ yang mengindikasikan bahwa hipotesis kedua diterima. Hasil ini mempunyai arti bahwa komitmen organisasi berpengaruh positif terhadap akuntabilitas pengelolaan dana desa. Hasil deskripsi jawaban responden pada lampiran 6 menunjukkan komitmen organisasi secara keseluruhan baik. Hal ini dapat dilihat dari keseluruhan rata-rata nilai komitmen organisasi yaitu 4,15. Nilai rata-rata tertinggi pada pernyataan "masalah yang terjadi dalam instansi menjadi permasalahan saya sebagai aparatur desa" dengan nilai rata-rata 4,23. Hal ini menunjukkan bahwa aparatur desa merasa bertanggung jawab untuk mengatasi permasalahan-permasalahan yang muncul di desa setempat.

Berdasarkan teori stewardship yaitu pihak yang dipercaya dalam akuntabilitas pengelolaan dana desa adalah aparatur desa. Aparatur desa yang memilki komitmen organisasi yang tinggi akan mempertanggungjawabkan segala kegiatan yang dilakukannya dalam organisasi untuk mewujudkan pelayanan yang baik kepada publik dan dapat mencapai pengelolaan anggaran yang efektif. Berdasarkan dari teori kepatuhan, setiap aparatur desa diwajibkan memiliki komitmen untuk tetap menerapkan peraturan perundanga-undangan desa yang telah berlaku, sehingga dengan tingginya komitmen organisasi, aparatur desa dapat selalu bertindak hati-hati dan memberikan dampak positif bagi desa.

Komitmen organisasi merupakan suatu sikap individu dalam bekerja sesuai dengan tujuan organisasi dikarenakan individu tersebut merasa bahwa ia juga bagian dari organisasi (Rulyanti et al., 2018). Seseorang yang memiliki komitmen terhadap organisasi akan mengupayakan kemampuannya untuk mewujudkan pencapaian akuntabilitas. Hasil penelitian ini sejalan dengan 
penelitian yang dilakukan oleh Handayani \& Setiawan (2019), Nurdin \& Wijaya (2019), Rulyanti et al. (2018), Utari \& Sujana (2019) dan Mariska et al. (2018) memberikan hasil penelitian yaitu komitmen organisasi berpengaruh positif terhadap akuntabilitas pengelolaan dana desa.

Hasil pengujian hipotesis mengenai pengaruh kejelasan sasaran anggaran terhadap akuntabilitas pengelolaan dana desa diperoleh nilai signifikansi sebesar 0,029 lebih kecil dari $a=0,05$ yang mengindikasikan bahwa hipotesis ketiga diterima. Hasil ini mempunyai arti bahwa kejelasan sasaran anggaran berpengaruh positif terhadap akuntabilitas pengelolaan dana desa. Hasil deskripsi jawaban responden pada lampiran 6 menunjukkan kejelasan sasaran anggaran secara keseluruhan baik. Hal ini dapat dilihat dari keseluruhan ratarata nilai kejelasan sasaran anggaran yaitu 4,14. Nilai rata-rata tertinggi pada pernyataan "anggaran yang dibuat telah mempertimbangkan skala prioritas" dengan nilai rata-rata 4,25. Hal ini menunjukkan bahwa aparatur desa menetapkan kejelesan sasaran anggaran sesuai dengan skala prioritas.

Hasil penelitian ini mendukung teori stewardship terkait dengan kejelasan sasaran anggaran, dimana aparatur desa dapat menjelaskan eksistensi aparatur desa (steward) memiliki kewajiban untuk memberikan pertanggungjawaban, menyajikan, melaporkan, dan mengungkapkan segala aktivitas dan kegiatan sesuai dengan tujuan sasaran anggaran dana desa yang telah ditetapkan yang menjadi tanggung jawabnya melalui kejelasan sasaran anggaran (Lewier \& Kurniawan, 2016). Selain itu, kejelasan sasaran anggaran berkaitan dengan konsep dari teori kepatuhan karena mampu mencegah terjadinya tindak kecurangan atau ketidakpatuhan oleh perangkat desa dalam menjalankan proses penyusunan anggaran, sehingga dapat mewujudkan akuntabilitas.

Kejelasan sasaran anggaran adalah sejauh mana tujuan anggaran ditetapkan secara jelas dan spesifik dengan tujuan anggaran dapat dimengerti oleh orang yang bertanggungjawab atas pencapaian sasaran anggaran tersebut (Kenis, 1979). Kejelasan sasaran anggaran yang di rancang sesuai dengan kebutuhan prioritas desa serta mempertimbangkan rencana jangka pendek dan rencana jangka panjang.

Hasil penelitian ini sejalan dengan penelitian yang dilakukan oleh Arta \& Rasmini (2019), Judarmita \& Supadmi (2017), Wijaya \& Suardana (2020), Yoga \& Wirawati (2020), dan Supadmi \& Suputra (2018) memberikan kesimpulan yang sama yaitu kejelasan sasaran anggaran berpengaruh positif terhadap akuntabilitas pengelolaan dana desa.

\section{SIMPULAN}

Semakin tinggi kompetensi yang dimiliki aparatur desa dalam mengelola dana desa, maka akuntabilitas pengelolaan dana desa semakin baik. Semakin tinggi komitmen organisasi yang dimiliki oleh aparatur desa dalam mengelola dana desa, maka akuntabilitas pengelolaan dana desa semakin baik. Semakin jelas sasaran anggaran dalam mengelola dana desa, maka semakin baik akuntabilitas pengelolaan dana desa.

Upaya yang dapat dilakukan untuk meningkatkan kompetensi aparatur desa dengan melengkapi sarana dan prasarana serta mengikuti kegiatan pelatihan mengenai keterampilan dan keahlian (skill), sehingga aparatur desa 
dapat meningkatkan produktivitas kerja dan kompetensi yang dimiliki akan semakin meningkat, Upaya yang dapat dilakukan untuk meningkatkan komitmen organisasi diantaranya mengadakan kegiatan pelatihan berupa pembentukan karakter pribadi yang bisa meningkatkan komitmen mereka dan saling memotivasi antar aparatur desa dengan cara memberikan dorongan serta mengarahkan setiap individu untuk berkomitmen dalam bekerja secara maksimal, sehingga dapat memberikan kontribusi yang lebih optimal terhadap desa. Upaya yang dapat dilakukan untuk meningkatkan kejelasan sasaran anggaran diantaranya dengan selalu bersosialisasi dan melakukan kegiatan pelatihan penyusunan anggaran dan perencanaan, sehingga aparatur desa dapat lebih memahami akan sasaran anggaran pada suatu desa. Selain itu Penelitian selanjutnya diharapkan dapat menggunakan variabel-variabel lain yang berpengaruh pada akuntabilitas pengelolaan dana desa. Misalnya dengan menggunakan variabel partisipasi masyarakat.

Penelitian ini hanya terbatas pada sampel, karena adanya keterbatasan waktu dan jarak lokasi penelitian ini hanya bisa dilakukan pada 30 desa di Kabupaten Buleleng yang melibatkan 4 responden di masing-masing desa. Pada penelitian selanjutnya diharapkan dapat melakukan penelitian dengan topik yang serupa namun pada lokasi dan jumlah responden yang lebih besar. Selain itu, Variabel - variabel bebas yang diteliti dalam penelitian ini dengan nilai $R$ Square sebesar 0,660 atau 66,0 persen yang menunjukkan bahwa model prediksi pada penelitian ini belum mewakili keseluruhan aspek yang mempengaruhi akuntabilitas pengelolaan dana desa. Sehingga perlu dilakukan kembali penelitian selanjutnya dengan mempertimbangkan variabel-variabel lain yang dapat mempengaruhi akuntabilitas pengelolaan dana desa agar kedepannya bisa terbentuk model prediksi yang komprehensif.

\section{REFERENSI}

Afrida, R. (2017). Pengaruh Kejelasan Sasaran Anggaran, Budaya Organisasi, Kualitas Sistem Pelaporan Terhadap Pengukuran Kinerja Instansi Pemerintahan Daerah (Studi Kasus pada SKPD Padang). Jurnal Akuntansi, 5(2), 1-24. https://doi.org/10.29303/akurasi.v2i1.15

Alminanda, P., \& Marfuah, M. (2018). Peran Komitmen Organisasi Dalam Memoderasi Pengaruh Kompetensi Sumber Daya Manusia, Sistem Pengendalian Intern Dan Pemanfaatan Teknologi Informasi Terhadap Kualitas Laporan Keuangan Pemerintah Daerah. Jurnal Analisis Bisnis Ekonomi, $16(2)$,

118-132. https://doi.org/10.31603/bisnisekonomi.v16i2.2620

Ardi. (2019). 29 Desa di Kabupaten Buleleng terancam tak cairkan dana desa tahap III tahun 2019. BaliPuspaNews.Com.

Arta, I. M. A. S., \& Rasmini, N. K. (2019). Pengaruh Kejelasan Sasaran Anggaran, Sistem Pelaporan dan Partisipasi Masyarakat Pada Akuntabilitas Pengelolaan Dana Desa. E-Jurnal Akuntansi, 26(1), 709-735. https://doi.org/10.24843/ eja.2019.v26.i01.p26

Aryani, N. P. D. E., Werastuti, D. N. S., \& Adiputra, I. M. P. (2020). Pengaruh Kompetensi Aparatur Pemerintah Desa, Efektivitas Kinerja Pendamping Lokal Desa Dan Keterlibatan Masyarakat Terhadap Pengoptimalan 
Pengelolaan Dana Desa. Wahana: Jurnal Ekonomi, Manajemen Dan Akuntansi, 11(2), 515-537.

Asmawati, I., \& Basuki, P. (2019). Akuntabilitas Pengelolaan Dana Desa. Jurnal Studi Akuntansi Dan Keuangan, 2(1), 63-76.

Atmadja, A. T., \& Saputra, K. A. K. (2018). Determinant factors influencing the accountability of village financial management. Academy of Strategic Management Journal, 17(1), 158-167.

Aulia, P. (2018). Pengaruh Kompetensi Aparat Pengelola Dana Desa, Komitmen Organisasi Pemerintah Desa, Pemanfaatan Teknologi Informasi, Dan Partisipasi Masyarakat Terhadap Akuntabilitas Pengelolaan Dana Desa Di $\begin{array}{llllll}\text { Kabupaten } & 50 \quad \text { Kot. } \quad J O M \quad \text { FEB, } & 1(2),\end{array}$ https:// doi.org/10.35800/jjs.v8i2.17199

Dewi, N. K. A. J. P., \& Gayatri, G. (2019). Faktor-Faktor Yang Berpengaruh Pada Akuntabilitas Pengelolaan Dana Desa. E-Jurnal Akuntansi, 26(2), 1269-1298. https://doi.org/10.24843/eja.2019.v26.i02.p16

Edison, E., Anwar., Y., \& Komariyah, I. (2016). Manajemen Sumber Daya Manusia. Bandung: CV. Alfabeta.

Ghozali, I. (2018). Multivariate Analysis Application with IBM SPSS 25 Program. Diponegoro University Publishing Agency.

Handayani., \& Setiawan, A. (2019). Pengaruh Kompetensi Aparatur, Komitmen Organisasi Dan Ketaatan Pada Peraturan Perundangan Terhadap Akuntabilitas Pengelolaan Keuangan Desa. Jurnal IAIN Surakarta, 2(1), Jurnal IAIN Surakarta. 2 (1), hal. 121-142.

Hardiningsih, P., Udin, U., Masdjojo, G. N., \& Srimindarti, C. (2020). Does competency, commitment, and internal control influence accountability? Journal of Asian Finance, Economics and Business, 7(4), 223-233. https:// doi.org/10.13106/JAFEB.2020.VOL7.NO4.223

Indrayani, L. F., Diatmika, P. G., \& Wahyuni, M. A. (2017). Pengaruh Komitmen Organisasi, Kejelasan Sasaran Anggaran dan Efektivitas Pengendalian Internal Terhadap Akuntabilitas Kinerja Organisasi Publik (Studi Empiris pada Satuan Kerja Perangkat Daerah Kabupaten Gianyar). JIMAT (Jurnal Ilmiah Mahasiswa Akuntansi) Undiksha, 1(2), 112-131.

Judarmita, I. N., \& Supadmi, N. L. (2017). Pengaruh Kejelasan Sasaran Anggaran, Sistem Pelaporan dan Audit Kinerja Terhadap Akuntabilitas Pengelolaan Dana Desa I. E-Jurnal Akuntansi Universitas Udayana, 21(3), 1719-1746.

Kenis, I. (1979). Effects of Budgetary Goal Characteristics on Managerial Attitudes and Performance. The Accounting Review, 54(4), 707-721.

Ladapase, L. I. M. (2019). Pengaruh Kompetensi Aparatur, Motivasi Aparatur, Dan Komitmen Organisasi Terhadap Akuntabilitas Pengelolaan Dana Desa Di Kecamatan Nelle, Kecamatan Koting, Dan Kecamatan Kangae Kabupaten Sikka. Skripsi: :Program Studi Akuntansi Jurusan Akuntansi Fakultas Ekonomi Universitas Sanata Dharma Yogyakarta.

Lewier, C. N., \& Kurniawan, H. (2016). Pengaruh Penyajian Laporan Keuangan Daerah Dan Aksesibilitas Laporan Keuangan Daerah Terhadap Akuntabilitas Pengelolaan Keuangan Daerah Kabupaten Klaten. The SAGE Encyclopedia of Social Science Research Methods, 5(1), 113-127.

Mada, S., Kalangi, L., \& Hendrik, G. (2017). Pengaruh Kompetensi Aparat 
Pengelola Dana Desa, Komitmen Organisasi Pemerintah Desa, dan Partisipasi Masyarakat Terhadap Akuntabilitas Pengelolaan Dana Desa Di Kabupaten Gorontalo. Jurnal Riset Akuntansi Dan Auditing, 3(1), 106-115.

Mahayani, N. L. A. (2017). Prosocial Behavior dan Persepsi Akuntabilitas Pengelolaan Dana Desa Dalam Konteks Budaya Tri Hita Karana. Jurnal Ilmiah Akuntansi Dan Bisnis, 12(2), 129-144.

Mardiasmo. (2009). Akuntansi Sektor Publik. Yogyakarta: Andi.

Mariska, W., Damayanti, R. A., \& Y., R. (2018). The Effect Of Competence, Commitment, And Regulation On The Accountability Of Village Financial Management With Moderated Spirituality. International Journal of Advanced Research, 6(8), 730-749. https://doi.org/10.21474/ijar01/7542

Medianti, L. (2018). Pengaruh Kompetensi Aparatur, Komitmen Organisasi dan Partisipasi Masyarakat terhadap Pengelolaan Dana Desa (Studi Empiris pada Desa - Desa di Kabupaten Bintan). Jom Feb, 1(1), 20-32.

Nurdin, Y., \& Wijaya, I. (2019). Pengaruh Kompetensi Akuntansi Aparat Pengelola Dana Desa dan Komitmen Organisasi Pemerintah Desa Terhadap Akuntabilitas Pengelolaan Dana Desa (Studi pada Kecamatan Sinjai Selatan Kabupaten Sinjai). Accounting, Accountability, and Organization System (AAOS) Journal, 1(1), 87-102.

Pebrianti, S., \& Aziza, N. (2019). Effect of Clarity of Budget Objectives, Accounting Control, Reporting Systems, Compliance with Regulation on Performance Accountability of Government Agencies. Advances in Social Science, Education and Humanities Research, 292, 396-410. https://doi.org/10.2991/agc-18.2019.62

Rahayu, S., \& Gudono. (2016). Faktor-Faktor yang Mempengaruhi Kemampuan Auditor dalam Pendeteksian Kecurangan : Sebuah Riset Campuran dengan Pendekatan Sekuensial Eksplanatif. Simposium Nasional Akuntansi XIX Lampung.

Rulyanti, D., Sularso, R. A., \& Sayekti, Y. (2018). Faktor-Faktor Yang Mempengaruhi Kinerja Pemerintah Desa Melalui Pengelolaan Keuangan Desa Sebagai Variabel Intervening. Bisma, 11(3), 323-335. https://doi.org/10.19184/bisma.v11i3.6474

Sjafrina, A., Primayogha, E., \& Ramadhana, K. (2017). Cegah Korupsi Dana Desa. Indonesian Corruption Watch. https://www.antikorupsi.org/id

Suarna, N. (2020). Tersandung Korupsi APBDes, Perbekel Pemecutan Kaja Ditahan. Bali Express. https://baliexpress.jawapos.com/

Sugiyono. (2017). Metode Penelitian Pendidikan (Pendekatan Kuantitatif, Kualitatif dan RED). Alfabeta.

Supadmi, N. L., \& Suputra, D. G. D. (2018). Pengaruh Kapasitas Sumber Daya Manusia, Kejelasan Sasaran Anggaran dan Sistem Pelaporan Keuangan Pada Akuntabilitas Pengelolaan Dana Desa di Kota Denpasar. Jurnal Ekonomi Dan Pariwisata, 13(2), 1190-1207.

Utari, N. W. D. P., \& Sujana, I. K. (2019). Implementasi Budaya THK dalam Pengaruh Komitmen OPD dan Partisipasi Masyarakat pada Akuntabilitas Pengelolaan Dana Desa. E-Jurnal Akuntansi, 28(3), 1715-1731. https:// doi.org/10.24843/ eja.2019.v28.i03.p06

Widiyarta, K., Herawati, N. T., \& Atmadja, A. T. (2017). Pengaruh Kompetensi 
Aparatur, Budaya Organisasi, Whistleblowing Dan Sistem Pengendalian Internal Terhadap Pencegahan Fraud Dalam Pengelolaan Dana Desa (Studi Empiris Pada Pemerintah Desa Di Kabupaten Buleleng). E-Journal S1 Ak Universitas Pendidikan Ganesha, 8(2).

Widyatama, A., Novita, L., \& Diarespati, D. (2017). Pengaruh Kompetensi Dan Sistem Pengendalian Internal Terhadap Akuntabilitas Pemerintah Desa Dalam Mengelola Alokasi Dana Desa (Add). Berkala Akuntansi Dan Keuangan Indonesia, 2(2), 1-20. https:/ / doi.org/10.20473/baki.v2i2.4762

Wijaya, I. K. K., \& Suardana, K. A. (2020). The Affecting Factors Accountability of Village Funds Management in Seririt Sub-District. International Journal of Management and Commerce Innovations, 7(2), 565-578.

Windyastuti, Fitriyani, L. Y., Marita, \& Afifah, M. N. (2019). Accountability and Transparency in Managing Village Funds in Ngawen, Blora, Central Java. E-Journal Faculty of Economics and Business, UPN “Veteran" Yogyakarta, 26(4), 177-178.

Yoga, I. K. S., \& Wirawati, N. G. P. (2020). Accountability Analysis of Village Fund Management. American Journal of Humanities and Social Sciences Research (AJHSSR), 4(5), 32-39. 